\title{
First record of the bivalve species Parvamussium fenestratum (Forbes, 1844) from the Middle Miocene of the Paratethys
}

\author{
Barbara STUDENCKA, Valentin A. PRYSYAZHNYUK and Svetlana A. LJUL'EVA
}

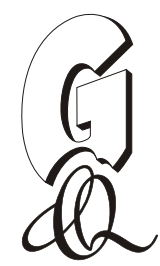

\begin{abstract}
Studencka B., Prysyazhnyuk V.A. and Ljul'eva S.A. (2012) - First record of the bivalve species Parvamussium fenestratum (Forbes, 1844) from the Middle Miocene of the Paratethys. Geol. Quart., 56 (3): 513-528, doi: 10.7306/gq.1037

This is the first Paratethyan record of a minute scallop species Parvamussium fenestratum (Forbes, 1844). The species was found in Middle Miocene (Upper Badenian) clayey deposits in the Surzha borehole, the Ukrainian Carpathian Foredeep Basin. Examination of other Parvamussium specimens stored in the Museum of the Earth in Warsaw and in the Hungarian Natural History Museum in Budapest revealed further Paratethyan records of Parvamussium fenestratum. These specimens, previously referred to Parvamussium felsineum (Foresti, 1893), were identified in the Middle Miocene faunas of Poland (Monastyrz and Długi Goraj, Roztocze Hills) and Hungary (Makkoshotyka, Tokaj Mts.). In the Mediterranean Neogene this extremely rare species has been reported from the Lower Miocene (uppermost Burdigalian) of Italy and from the Lower Pliocene (Zanclean) of Spain. Research on the Oligocene-Miocene succession in the Paratethys has shown representatives of Parvamussium Sacco, 1897 to be moderately abundant in clayey facies in different basins and the genus is regarded as biostratigraphically important. Data on the distribution of other Paratethyan and Neogene Mediterranean Parvamussium species viz., Parvamussium bronni (Mayer, 1861), P. duodecimlamellatum (Bronn, 1831), P. felsineum (Foresti, 1893) and P. miopliocenicum (Ruggieri, 1949) are reported. Finally, palaeobiological and palaeobiogeographical characteristics on the genus Parvamussium Sacco, 1897 the Early Cretaceous to Recent time span are described.
\end{abstract}

Barbara Studencka, Polish Academy of Sciences Museum of the Earth in Warsaw, Na Skarpie 20/26, 00-488 Warszawa, Poland, e-mail: bstudencka@go2.pl; Valentin A. Prysyazhnyuk, Svetlana A. Ljul'eva, Institute of the Geological Sciences, National Academy of Sciences of Ukraine, O. Gonchara 55b, 01-054 Kyiv, Ukraine, e-mail: prysval@mail.ru (received: May 19, 2012, accepted: June 20, 2012, first published online: September, 06, 2012).

Key words: Bivalvia, Pectinoidea, taxonomy, palaeobiogeography, Badenian, Paratethys.

\section{INTRODUCTION}

Bivalve fossil assemblages from the Upper Badenian deposits of the Volhynian-Podolian region were the first Ukrainian Miocene faunas that attracted the attention of palaeontologists at the beginning of the 19th century. Pioneering descriptions were made by Eichwald $(1829,1830$, 1850, 1853), Andrzejowski (1830, 1833), du Bois de Montpéreux (1831) and Pusch (1837). The bivalve content of the Upper Badenian near-shore assemblages from the siliciclastic (mainly sandy) facies of the shallow Foreland $\mathrm{Ba}-$ sin over the Podolian Massif in Ukraine is well known through descriptions by Hilber (1882), Niedźwiedzki (1889), Friedberg (1932, 1934-1936, 1938), Kazakova (1952) and Nevesskaja et al. (1993). Most of the hitherto described Ukrainian bivalves were recently reviewed and listed by Studencka et al. (1998). Much less emphasis was given to bivalves from the Upper Badenian coralline algae-vermetid reefs, widespread in
Ukraine, with the notable exceptions of Teisseyre (1895), Kudrin (1966), and Studencka and Jasionowski (2011).

In contrast to the attention focused on the Badenian bivalves from sandy and reefal carbonate facies in Ukraine, knowledge of bivalves from offshore siliciclastic facies (mainly clayey) of the Carpathian Foredeep Basin bordering the Carpathian arch along its periphery is patchy and full of gaps as regards systematic and taxonomic detail. Besides the paper by Zhizhchenko (1953), a limited number of bivalve assemblages from the Upper Badenian have been described and illustrated. Most probably, this is the consequence of the considerable thickness of Sarmatian strata overlaying the Upper Badenian. The thickness of the Sarmatian in the Ukrainian part of the Carpathian Foredeep Basin ranges from a few hundred to more than $5000 \mathrm{~m}$ (Andreyeva-Grigorovich et al., 1997; Kurovets et al., 2004).

The present bivalve study has been performed on samples from the Surzha borehole (Fig. 1) and provides the first fossil record of Parvamussium fenestratum (Forbes, 1844) in the 


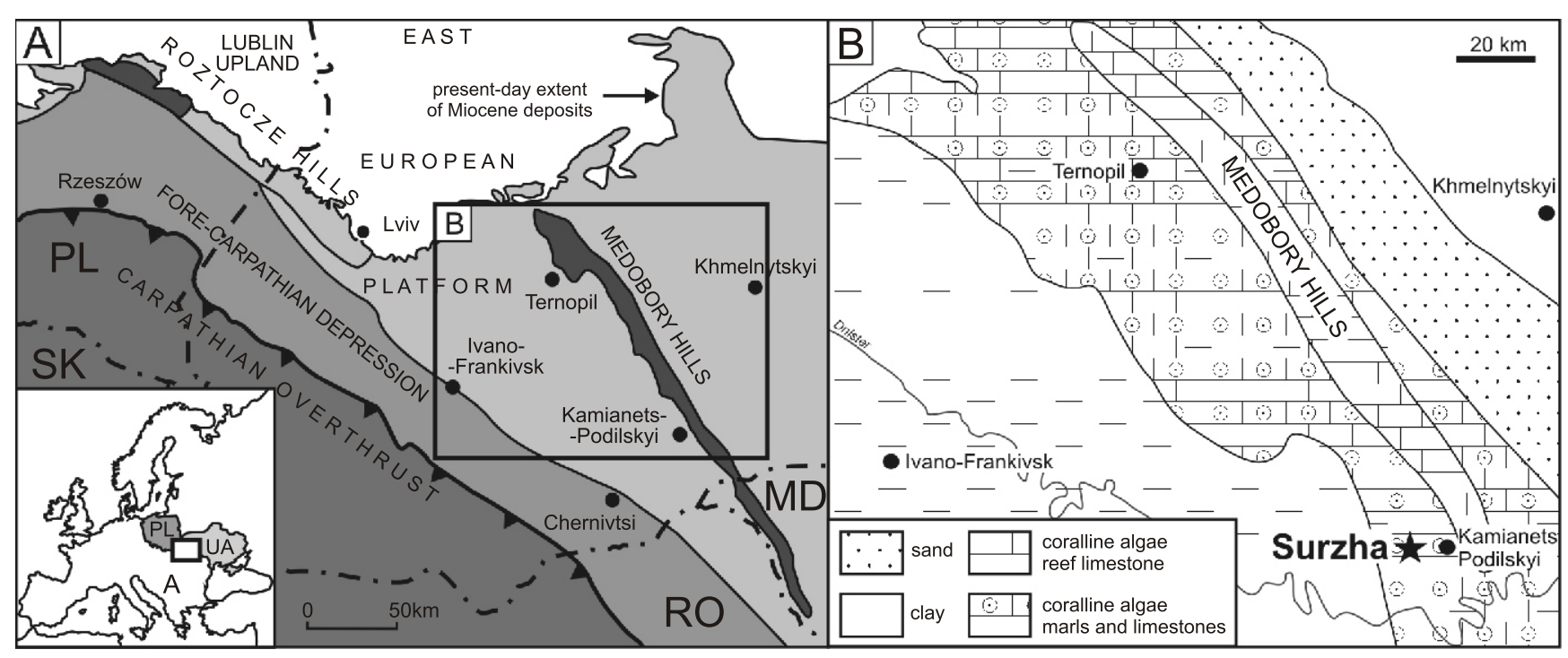

Fig. 1. Location of the borehole No 40 in Ukraine

\begin{abstract}
A - map of Middle Miocene deposits in the Carpathian Foredeep Basin in Poland and Ukraine (reefal deposits solid shading); B - map of Ukraine showing distribution of the Upper Badenian deposits during the maximum phase of transgression; the asterisk marks location of the borehole No 40; modified after Maslov and Utrobin (1958)
\end{abstract}

Central Paratethys. The bivalve fauna detected in cores represents only a small and random part of the entire fossil community, nevertheless, as information on the representatives of the genus Parvamussium Sacco, 1897 from the Paratethys is scarce, even a few specimens can provide important information on the distribution and palaeogeographic occurrence of its constitutive species.

\section{GEOLOGICAL CONTEXT}

The borehole No 40 located in the vicinity of the Surzha village (10 km W of Kamianets Podilskyi) was drilled west of the Medobory reefs in Ukraine (Fig. 1). It reached a depth of $93 \mathrm{~m}$ and ended in sedimentary rocks of Silurian age (Fig. 2). The core was sampled in 1979 by Dr. V. I. Didkowski for foraminifers, by Dr. Y. B. Ljul'ev for ostracods, and by Dr. S. A. Ljul'eva for calcareous nannoplankton (all results unpublished). Evaluation of the sample material has been restricted to internal reports of the Institute of Geological Sciences, Academy of Sciences of the USSR, Kiev. A brief summary of the lithological description presented below has been abstracted from these unpublished reports.

The Badenian-Sarmatian sequence is bipartite: coralline-algae marly limestones, $6 \mathrm{~m}$ thick, at the base, are overlain by a thick (about $87 \mathrm{~m}$ ), very homogeneous succession of fine-grained and mid-grained grey, grey-green and grey-brown claystones to siltstones with sandy and sandy limestone intercalations.

The base of the profile is constituted by the Ternopil Beds unit. It is represented by a $6 \mathrm{~m}$ thick succession of coralline-algae marly limestones which overlies the pre-Neogene basement with a considerable hiatus. In the lower part of the limestones two thin greyish-blue fine-grained sandy-silty intercalations with a molluscan fauna have been observed. Deposition of these limestones has been linked with the Late Badenian transgression (cf. Gedl and Peryt, 2011) and the development of the Medobory reefs located to the east (shorewards). The overlying Upper Badenian Kosiv Formation (Prut Beds) consists of $7 \mathrm{~m}$ of predominantly laminated grey-green or grey-blue clayey silt with occasional sandy limestone units containing a molluscan fauna.

The Prut Beds unit is followed by a succession about $80 \mathrm{~m}$ thick, composed predominantly of green-greyish clays with an admixture of sandstones, distinguished as the Sarmatian Dashava Formation. The stratigraphic succession of the Dashava Formation shows three distinct intervals. The lower interval, Kuzhora Beds, about $37 \mathrm{~m}$ thick, consists at the base of greyish-green laminated or massive clays intercalated with sands containing unidentifiable macrofloral and molluscan remains; the deposit changes upwards into green-grey laminated clays interbedded with very thin tuffite and bentonite laminae and sandy limestones with abundant marine bivalves. Some clay layers observed in the middle part of this interval (61.0-61.8 m) yielded shells of terrestrial snails. The next interval, the Zbruch Beds, up to $28 \mathrm{~m}$ thick, is a monotonous succession of greyish-green or green finely laminated clays with very thin tuffite laminae at the bottom and secondary gypsum at the top of the succession. The upper interval, the Novomoskovs'k Beds, about $15 \mathrm{~m}$ thick, is represented by green-grey laminated clays $(5.0-15.0 \mathrm{~m})$ and lumpy clays at the top. The Dashava Formation together with the clastic Upper Badenian succession indicate progressively shallowing facies deposited in a basin that was slowly desalted as reflected by a significant change in molluscan fauna (Andreyeva-Grigorovich et al., 1997).

\section{BIOSTRATIGRAPHY}

The following data refer exclusively to important or stratigraphically significant foraminifera and calcareous nannoplankton recorded in the Surzha core. 


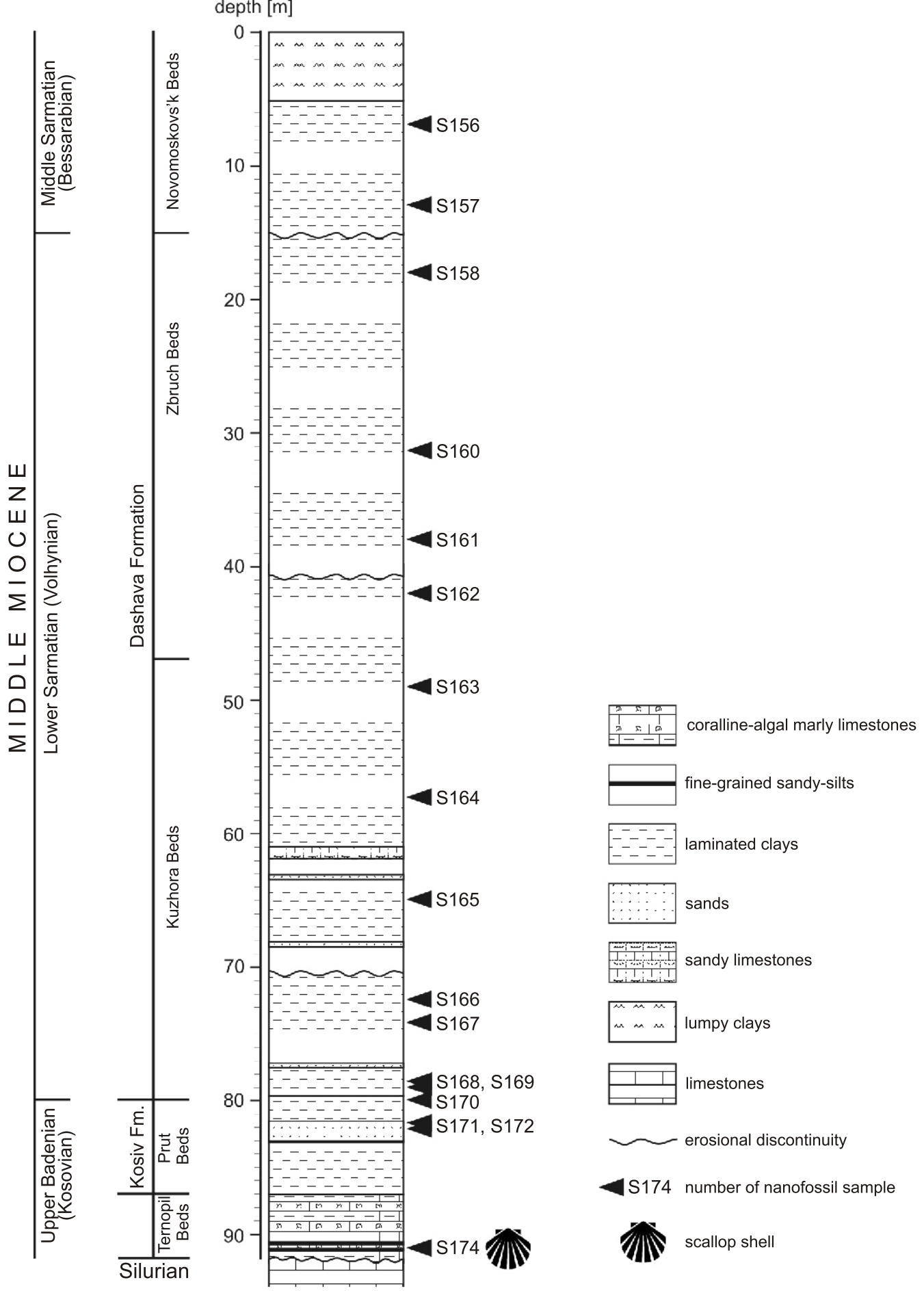

Fig. 2. Generalized sedimentological profile of Upper Badenian-Sarmatian deposits from the Surzha borehole with the position of the level with Parvamussium fenestratum and samples for calcareous nannofossils

FORAMINIFERAL DATA

Only a few samples turned out to be useful for biostratigraphic and/or palaeobathymetric purposes. Benthic foraminifers in greyish-blue fine-grained sandy-silty intercalations observed within the Ternopil Beds (91.15-91.20 m; 90.6-90.8 m) are dominated by taxa typical of the Bulimina-Bolivina Zone. They have also been detected in the Prut Beds that allows established a Late Badenian age for this unit.
The benthic foraminiferal assemblage in the middle part of the Dashava Formation (Zbruch Beds) yielded Elphidium macellum (Fichtel et Molle), E. aculeatum (d'Orbigny), Porosononion martcobi Bogdanowicz, Quinqueloculina consobrina d'Orbigny and Articulina problema Bogdanowicz suggesting the Early Sarmatian. The occurrence of Quinqeloculina problema Bogdanowicz, $Q$. consobrina (d'Orbigny), Q. reussi (Bogdanowicz), $Q$. voloschinovae Bogdanowicz and Bolivina sarmatica Didkowski 
in the uppermost part of the Badenian-Sarmatian succession (5.0-15.0 m) suggests a Middle Sarmatian age (comp. Didkowski et al., 1981).

\section{CALCAREOUS NANNOPLANKTON DATA}

Nannofossils were studied in 19 samples collected between 7.0 and $91.2 \mathrm{~m}$. Calcareous nannoplankton assemblages of medium diversity and abundance occurred in 17 samples. In total,
40 taxa have been determined (Table 1). Most abundantly represented are: Coccolithus pelagicus (Wallich), Reticulofenestra haquii Backman, Calcidiscus ex gr. leptoporus (Murray et Blackman), Helicosphaera carteri (Wallich), Sphenolithus neoabies Bukry et Bramlette, and Rhabdosphaera pannonica Báldi-Beke.

The genus Discoaster was found sporadically while a few specimens of $D$. exilis Martini et Bramlette, $D$. adamanteus Bramlette et Wilcoxon, D. braarudii Bukry, D. brouweri

Distribution and abundance of autochthonous calcareous nannofossils in the Surzha borehole

\begin{tabular}{|c|c|c|c|c|c|c|c|c|c|c|c|c|c|c|c|c|c|}
\hline Number of sample & 174 & 172 & 171 & 170 & 169 & 168 & 167 & 166 & 165 & 164 & 163 & 162 & 161 & 160 & 158 & 157 & 156 \\
\hline \multirow{2}{*}{ Species } & \multicolumn{17}{|c|}{ Depth $[\mathrm{m}]$} \\
\hline & 91.2 & 82.1 & 81.7 & 80.0 & 79.0 & 78.5 & 74.2 & 72.4 & 65.0 & 57.3 & 49.0 & 42.0 & 38.0 & 31.3 & 18.0 & 13.0 & 7.0 \\
\hline Coccolithus pelagicus & • & - & - & - & • & • & • & • & • & • & • & • & • & + & • & • & • \\
\hline C. miopelagicus & + & + & + & & & + & & + & & & & & & & + & & + \\
\hline Reticulofenestra haqii & $\cdot$ & $\cdot$ & $\cdot$ & $\cdot$ & $\cdot$ & & & + & • & & & + & + & + & & & + \\
\hline R. pseudoumbilica & & & + & + & + & & & & + & + & & + & & + & + & & + \\
\hline Calcidiscus premacintaryei & + & & & & & & & + & & & & & & & & & \\
\hline Ca. macintaryei & - & & + & & + & & & & + & & + & + & & • & & & \\
\hline Ca. leptoporus & + & + & + & + & 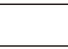 & & & & & + & $\cdot$ & $\cdot$ & $\bullet$ & & & & \\
\hline Cyclicargolithus floridianus & + & + & + & $\cdot$ & $\cdot$ & + & & $\cdot$ & $\bullet$ & + & - & $\cdot$ & - & & + & + & \\
\hline Coronocyclus nitescens & + & & & & + & & & & & + & & & & & & & \\
\hline Geminilithella rotula & + & & & + & + & & & 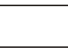 & + & + & & & & + & & & \\
\hline Helicosphaera carteri & $\cdot$ & $\cdot$ & $\cdot$ & $\cdot$ & • & $\cdot$ & - & $\cdot$ & • & + & + & + & + & & + & + & + \\
\hline H. intermedia & + & + & & & & & & + & & & & & & & & & \\
\hline H. walbersdorfensis & & + & & & + & & & + & & & + & & & & + & & \\
\hline H. spp. & & + & & & + & & & + & & & + & & & & & & \\
\hline Sphenolithus abies & & + & • & + & + & + & + & + & + & + & + & + & + & & & & \\
\hline Sph. neoabies & + & + & $\cdot$ & $\cdot$ & $\cdot$ & + & & & & + & & + & & & & & + \\
\hline Sph. moriformis & + & & + & + & + & & + & + & + & + & + & + & + & & & & \\
\hline Rhabdosphaera pannonica & + & + & $\cdot$ & + & $\cdot$ & & + & + & + & + & + & & + & & & & + \\
\hline Discotithina multipora & • & + & + & + & + & + & & + & + & + & & & + & & & & + \\
\hline Syracosphaera lunaria & & + & & & & & & & & + & & + & & & & & \\
\hline Braarudosphaera bigelowi & $\bullet$ & + & + & 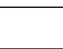 & $\bullet$ & + & + & + & + & + & & + & & $\bullet$ & & • & $\cdot$ \\
\hline Holodiscolithus macroporus & + & & + & + & + & + & & + & & + & + & + & & & & & \\
\hline Lithostromation perdurum & & & + & + & & & & & & & & & & & & & \\
\hline Thoracosphaera albatrosina & + & + & & + & + & + & & & + & & + & & + & & + & & $\cdot$ \\
\hline Th. heimi & & & & & & & & & & & & & & & + & + & + \\
\hline Scyphosphaera globulata & + & & & & & & & & & & & & & & & & \\
\hline Sc. recurvata & & & + & & & & & & & & & & & & & & \\
\hline Sc. amphora & & + & & & & & & & & & & & & & & & \\
\hline Triquetrorhabdulus sp. & $\bullet$ & + & & & & + & & & & & & & & & & & \\
\hline Pseudotriquetrorhabdulus sp. & & & + & & + & & & + & + & + & & & & & & & \\
\hline Discoaster exilis & & & & & & & + & + & + & + & & & & & + & + & \\
\hline D. variabilis & & & & & + & & & + & & + & & + & & & & & \\
\hline D. braarudii & & & & + & & & & & & & & & & & & & \\
\hline D. extensus & & & & & & & + & & + & + & + & & & & & & \\
\hline D. adamanteus & & & + & & & + & & & + & & + & + & & & & & \\
\hline D. cf. bollii & & & & & & & & & + & & + & & & & & & \\
\hline D. deflandrei & + & & + & & & + & & & + & + & + & + & & & & & \\
\hline D. brouweri & & & & + & & & & + & & & & & & & & & \\
\hline Scapholithus fossilis & & + & & & & & & & & & & & & & & & \\
\hline Perfocalcinella gr. fusiformis & + & + & + & + & + & + & + & + & + & + & + & + & + & + & + & + & + \\
\hline
\end{tabular}


(Tan), D. deflandrei Bramlette et Riedel, and D. variabilis Martini et Bramlette have been detected in samples from both the Upper Badenian and Sarmatian deposits. Occasional occurrences of Discoaster exilis along with the absence of Sphenolithus hetromorphus Deflandre and Discoaster kugleri Martini et Bramlette indicate that major part of the Sarmatian Dashava Formation can be determined as the NN6 Zone ( $c f$. Andreyeva-Grigorovich et al., 1997; Peryt, 1999; Garecka and Olszewska, 2011). In the samples studied Discoaster kugleri, the index species for NN7 Zone, has not been identified but its occurrence was documented within the Zbruch Beds in the same region of Ukraine (Lyulyeva, 2009). In some samples, a significant number of calcareous nannoplankton tests reworked from older deposits was observed, Cretaceous taxa being dominant. In samples 163-166, 168 and 171, however, apart from Paleogene and Miocene reworked specimens of Sphenolithus heteromorphus, index species for the NN5 Zone are common.

\section{MOLLUSCAN RECORD}

Except for two thin greyish-blue fine-grained sandy-silty intercalations (91.15-91.20 m; 90.6-90.8 m), the Ternopil Beds practically lack fauna. Gastropods in these intercalations are almost exclusively represented by Bittium cf. deforme (Eichwald), naticids and small trochids. The bivalve faunas are of low diversity and are dominated by two species: Pseudamussium lilli (Pusch) and Parvamussium fenestratum (Forbes), whereas Nucula (Nucula) nucleus (Linnaeus), Nuculana (Saccella) fragilis (Chemnitz), Anadara (Anadara) cf. diluvii (Lamarck), Modiolus sp. and Parvicardium sp. are rare. In addition, intermediate valves of the chiton species Acanthochitona faluniensis (Rochebrunne) are found. The scallop species Parvamussium fenestratum (Forbes, 1844), being the focus of this study, is described in the chapter "Systematic description". In sandy limestones of the Upper Badenian Prut Beds (83.0-83.1 m) small trochids were documented. Of great importance is the occurrence in the Prut Beds (81.5-83.0 m) of representatives of the opportunistic bivalve species Obsoletiforma cf. lithopodolica (du Bois), Abra (Syndosmya) reflexa (Eichwald) and Ervilia podolica (Eichawald) characteristic of the Early Sarmatian. These taxa are recognized as indicators of a stressed environment with fluctuating salinity (comp. Studencka and Jasionowski, 2011).

In sandy intercalations within the lowermost part of the Lower Sarmatian Kuzhora Beds (77.1-77.5, 67.9-68.0 and 63.9-64.0 m) cerithid shells along with Ervilia podolica (Eichwald) and Ervilia trigonula (Sokolov) are ubiquitous. Some layers with coarse material and shell concentrations of Ervilia podolica (Eichwald) and Obsoletiforma lithopodolica (du Bois) were observed in the middle part of the Kuzhora Beds (61.0-61.8 m). Thin clayey intercalations occurring within this bivalve coquina contain either shells of the terrestrial snails Pupilla sp., Gastrocopta fissidens (Sandberger), Gastrocopta ex gr. serotina Lozek, Microstele sp., Oxychilus sp. and Ceptaea sp., or bivalve shells of the marine species Inaequicostata pia (Zhizhchenko) and Abra (Syndosmya) reflexa (Eichwald).
In the Zbruch Beds $(15.0-42.7 \mathrm{~m})$ the molluscan fauna is almost exclusively represented by the bivalve genus Inaequicostata Kojumdgieva but locally scattered shells of Mactra (Sarmatimactra) eichwaldi (Laskarew), Obsoletiforma lithopodolica (du Bois) and Venerupis sp. occur. In the upper unit of the Dashava Formation (5.0-15.0 m) imprints of shells of Obsoletiforma cf. obsoleta (Eichwald) only were documented.

\section{SYSTEMATIC DESCRIPTION}

Previous research on the Middle Miocene succession in the Carpathian Foredeep Basin has shown the minute scallop genus Parvamussium Sacco to be rarely encountered (Zhizhchenko, 1953; Krach and Nowak, 1956; Krach, 1957; Jakubowski and Musiał, 1977). Among the rarest bivalves detected in the core of the Surzha borehole is Parvamussium fenestratum (Forbes, 1844). This is the first Paratethyan record of this species that justifies the need of its detailed taxonomic study. The Ukrainian specimens of $P$. fenestratum documented herein are deposited in the Polish Academy of Sciences Museum of the Earth in Warsaw (abbr. MZ), under the inventory numbers MZ VIII Ml-3863.

Systematic arrangement of Pectinoida is here adopted according to Bieler et al. (2010).

Order PECTINOIDA Gray, 1854

Superfamily PECTINOIDEA Rafinesque, 1815

(with family-level content following Waller, 2006)

Family PROPEAMUSSIIDAE Abbott, 1954

Parvamussium Sacco, 1897

Type species: Pecten (Pleuronectes) duodecimlamellatus

Bronn, 1831 (by original designation)

Comments. - The species Pecten (Pleuronectes) duodecimlamellatus was created by Bronn (1831, p. 116) on the basis of material found at Tabbiano near Piacenza in the Pliocene of Emilia-Romagna, Italy. The original description was merely a short note without figures. The Italian specimens were illustrated by Sacco (1897, pl. 14, figs. 2-6) but none of them come from the type locality. Recently, the shell from Tabbiano stored in the Naturhistorisches Museum in Basel, Switzerland was illustrated by Löffler (1999, pl. 28, figs. 1-4). The shell illustrated (height $16 \mathrm{~mm}$ ) is oblong in outline (higher than wider) and almost equivalved. Right valve with closely spaced, regularly arrangement commarginal lamellae, weakly expressed in the early growth stage. Left valve is smooth. Hinge line straight. Internal surface has eleven prominent radial ribs extending to the ventral margin.

The first brief description by Bronn (1831) was followed by a more comprehensive description by Deperet and Roman (1928, p. 180-182). They were the first who noted that the shape of $P$. duodecimlamellatum changes with size. Small shells (up to 5-7 mm high) derived from Tortonian at Sant'Agata in Piedmont, Italy, are almost circular in outline, with a larger apical angle and internal riblets showing flabellate arrangement. By contrast, larger shells from the same locality, more than $9 \mathrm{~mm}$ in 
height, are oblong in outline, with a smaller apical angle ( $c a$. 85 degrees) and with straight internal riblets extending to the ventral margin (Deperet and Roman, 1928, pl. 27, fig. 4, 4a). Finally, specimens of $P$. duodecimlamellatum (10 mm high) from Sant'Agata were illustrated by Robba (1968, pl. 37, figs. 4a-5b), and a small specimen ( $6 \mathrm{~mm}$ high) from the collections of the Claude Bernard University in Lyon, France, originally illustrated by Deperet and Roman (1928, pl. 27, fig. 6a, b) was reproduced by Hertlein (1969, N350, fig. C73. 2a, b).

For a specimen from Pliocene deposits at Ponticello in the Val Savena near Bologna (19 mm high) Foresti (1893, p. 381) proposed the variety name gigantea. The largest specimen, 30 $\mathrm{mm}$ high, was found at Bordighera in the Middle Pliocene of Italy (Sacco, 1897, pl. 14, fig. 4).

\section{Parvamussium fenestratum (Forbes, 1844) (Figs. 3-5)}

1897 Variamussium cf. fenestratum (Forb.); Sacco, p. 50, pl. 14, fig. 24 1939 Chlamys fenestrata Forbes; Roger, p. 220, 221.

part. 1960 Amussium felsineum Foresti; Csepreghy-Meznerics, p. 18, 19, pl. 35, figs. 13-15.

1966 Amussium felsineum For.; Csepreghy-Meznerics, pl. 2, figs. 1, 2

part. 1977 Propeamussium (Parvamussium) felsineum (Foresti, 1895); Jakubowski, p. 91-92, pl. 5, figs. 11-13, pl. 6, figs. 1, 2.

1990 Propeamussium fenestratum (Forbes, 1844); Smriglio and Mariottini, p. 5, 6, pl. 1, fig. 4a-d

1993 Propeamussium fenestratum (Forbes); Poppe and Goto, p. 70, pl. 10, fig. 5

1995 Propeamussium fenestratum (Forbes, 1844); Vera-Peláez et al., p. 100.

1997 Parvamussium fenestratum (Forbes, 1844); Lozano-Francisco, p. 315-317, pl. 33, figs. 1-11.

2002 Parvamussium fenestratum (Forbes, 1844); Dijkstra and Goud, p. 36-38, figs. 5-12.

2004 Parvamussium fenestratum (Forbes, 1844); Dijkstra and Gofas, p. 39-42, figs. 4, 5.

T y p e mate ri a 1. - The holotype was originally not designed. Syntypes are stored in the National Museum of Scotland in Edinburgh, under the inventory numbers RSM 1976.5.31902, 3. Type locality not designed (see Dijkstra and Gofas, 2004).

Stratigraphic range and geog r a p h i c d i s t r i b u t i o n. - Early Miocene to Recent; previous fossil records are restricted to the Mediterranean. This extraordinarily rare species has been reported in the Lower Miocene only from Burdigalian strata, at Sciolze, Italy (Sacco, 1897). Its occurrence in the Pliocene has been confirmed in the Estapona Basin, Spain by Vera-Peláez et al. (1995) and Lozano-Francisco $(1997,1998)$. It is noteworthy that through the Mediterranean the present-day $P$. fenestratum seems to be scarce (Smriglio and Mariottini, 1990; Poppe and Goto, 1993). Recently, living specimens have been found only in a few localities on the muddy bottoms around the scleractinian coral banks at $530 \mathrm{~m}$ depth in the Ionian Sea off Apulia, Italy (Mastrototaro et al., 2010) and its presence off Capo Corso in the Corsica from $300 \mathrm{~m}$ depth was communicated to the senior author by B. Dell'Angelo in 2011. On the other hand, modern $P$. fenestratum is widespread throughout the northeastern Atlantic and is distributed from Iceland along the British Isles, on the Galician Bank, on the Lusitanian seamounts, south to Portugal, the Azores, Madeira, Canary Islands and the Cape Verde Islands (Poppe and Goto, 1993; Dijkstra and Goud, 2002; Dijkstra and Gofas, 2004; Dijkstra et al., 2009).

$\mathrm{M}$ a $\mathrm{t}$ e $\mathrm{r}$ i a 1 . - Four right valves and fragments of two left valves embedded in sediment (MZ VIII Ml-3863; Table 2).

Other material ex a mined. - Two right valves and two left valves and numerous disc fragments (MZ VIII Ml-681) from Monastyrz (Roztocze Hills, Poland); two right valves and ten disc fragments (MZ VIII Ml-682) from Długi Goraj (Roztocze Hills, Poland); two right valves and two left valves (M63/3026, M63/5155 and M65/1042) from Makkoshotyka (Tokay Mts., Hungary) housed in the Hungarian Natural History Museum in Budapest (abbr. HNHM); two right valves and two left valves from Valerín-carretera near Estapona (Spain) stored in the Faculty of Sciences, University of Malaga (abbr. DGEM, L-F/1997).

Description of the Ukrainian specim e n s. - Only two right valves from the Surzha borehole are well-preserved. Shell thin, small, approximately $9 \mathrm{~mm}$ long, nearly circular in outline, weakly inflated. The external sculpture of the right and the left valve is different.

Right valve with unequal auricles: the anterior slightly larger than the posterior one, separated from the disc by a well-developed small byssal notch; no ctenolium. The small, orthogyrate beak is slightly projected. Hinge line is straight, weakly denticulate, its length approaching $85 \%$ of total disc length. Umbonal angle $c a$. 95 degrees. Whole external surface of the disc is covered by numerous, closely set, regularly arranged commarginal lamellae (11 lamellae per $\mathrm{mm}$ in the central part of the disc). Grooves are as wide as lamellae. Growth stages are invisible. Anterior auricle more prominently sculptured than the posterior one, with commarginal lamellae and distinct radial ribs. Internal surface with 18-20 radial ribs terminating at some distance from the smooth ventral margin.

Left valves are partially fragmented and auricles are missing. External surface of the left disc sculptured with irregularly spaced commarginal lamellae (less closely spaced than on the disc of right valve) and radial lirae; delicate reticulate sculpture is formed by their intersection. Growth stages are invisible. Interior surface of the left valve could not be observed.

$\mathrm{Tab} l$ e 2

Measurements [mm]

\begin{tabular}{|l|c|c|}
\hline \multicolumn{1}{|c|}{ Specimens No } & Length & Height \\
\hline RV, MZ VIII Ml-3863/1 & 2.2 & 2.0 \\
\hline RV, MZ VIII Ml-3863/2 & 6.0 & 5.2 \\
\hline RV, MZ VIII Ml-3863/3 & 9.0 & 8.0 \\
\hline LV, MZ VIII Ml-681 & 6.5 & 6.0 \\
\hline RV, MZ VIII Ml-682/1 & 8.1 & 7.0 \\
\hline RV, MZ VIII Ml-682/2 & 6.8 & 6.0 \\
\hline RV, HNHM M63/3026 & 8.1 & 7.1 \\
\hline LV, HNHM M63/3026 & 7.7 & 7.5 \\
\hline RV, DGEM, L-F/1997/1 & 4.2 & 4.0 \\
\hline LV, DGEM, L-F/1997/2 & 6.8 & 6.0 \\
\hline LV, DGEM, L-F/1997/3 & 7.0 & 6.8 \\
\hline
\end{tabular}



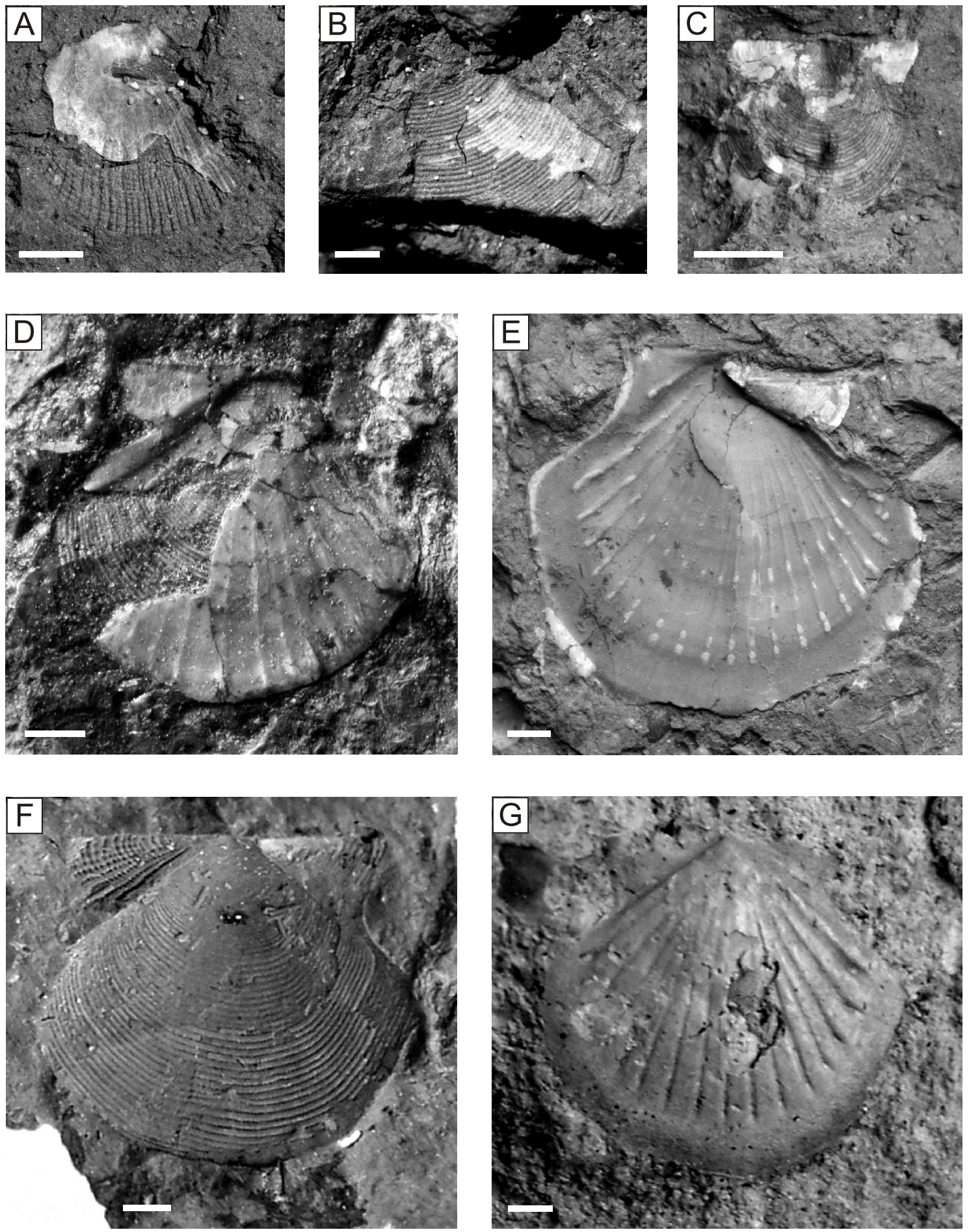

Fig. 3. Parvamussium fenestratum (Forbes, 1844)

A-E - Surzha, Ukraine, Middle Miocene (Upper Badenian), F, G-Makkoshotyka in the Tokay Mts., Hungary, Middle Miocene (Upper Badenian); A - imprint of left valve exterior (MZ VIII Ml-3863/4); B - imprint of right valve exterior (MZ VIII Ml-3863/5); C - imprint of right valve exterior (MZ VIII Ml-3863/1); D - interior view of right valve (MZ VIII Ml-3863/2); E - interior of right valve (MZ VIII Ml-3863/3); F - imprint of right valve exterior (HNHM M63/3026); G - mould of interior left valve (HNHM M63/3026); scale bars $1 \mathrm{~mm}$ 


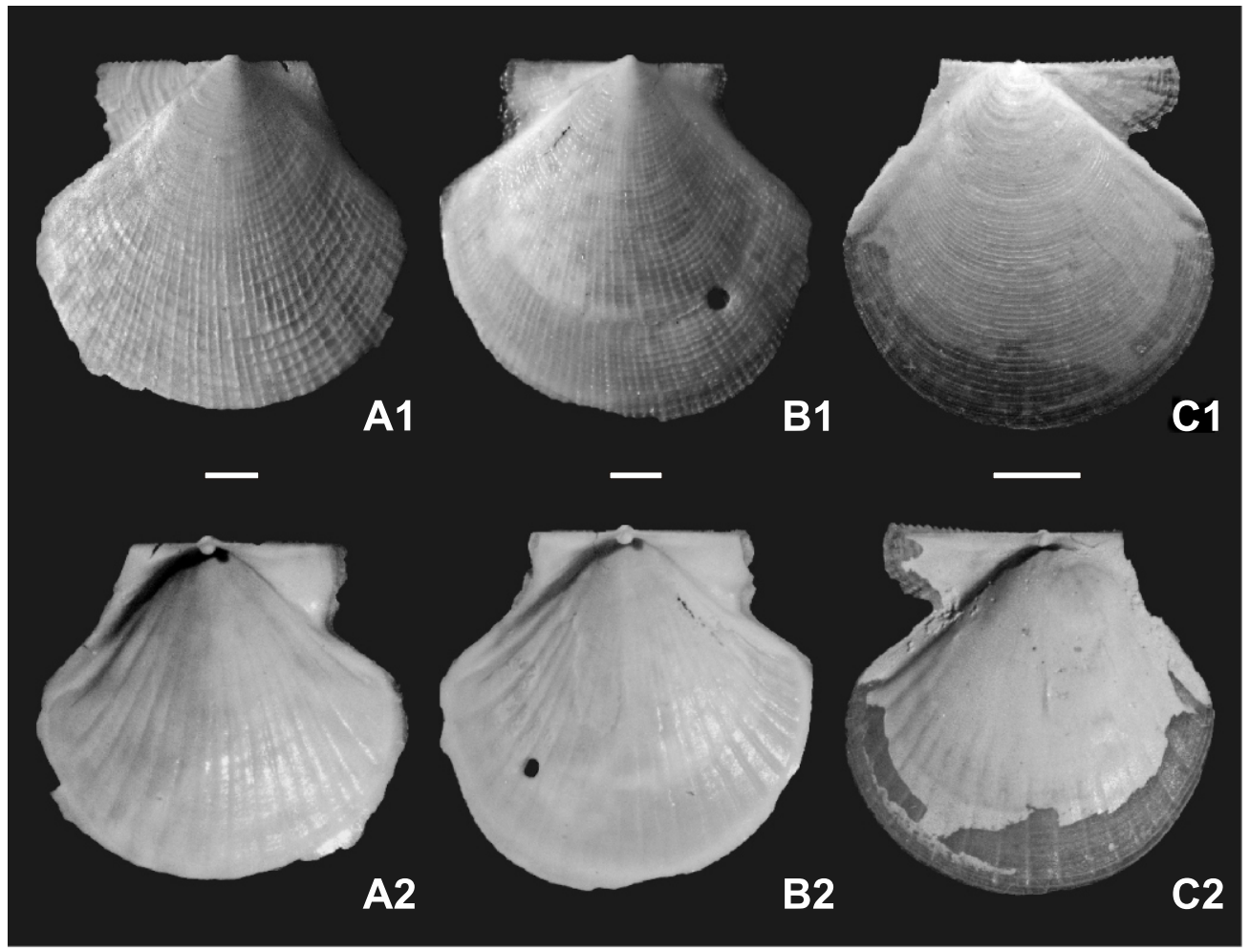

Fig. 4. Parvamussium fenestratum (Forbes, 1844) fromValerín-carretera near Estapona, Spain, Lower Pliocene (Zenclean)

A1, A2 - exterior and interior views of left valve (DGEM, L-F/1997/3); B1, B2 - exterior and interior views of left valve (DGEM, L-F/1997/2); C1, C2 - exterior and interior views of right valve (DGEM, L-F/1997/1); scale bars $1 \mathrm{~mm}$

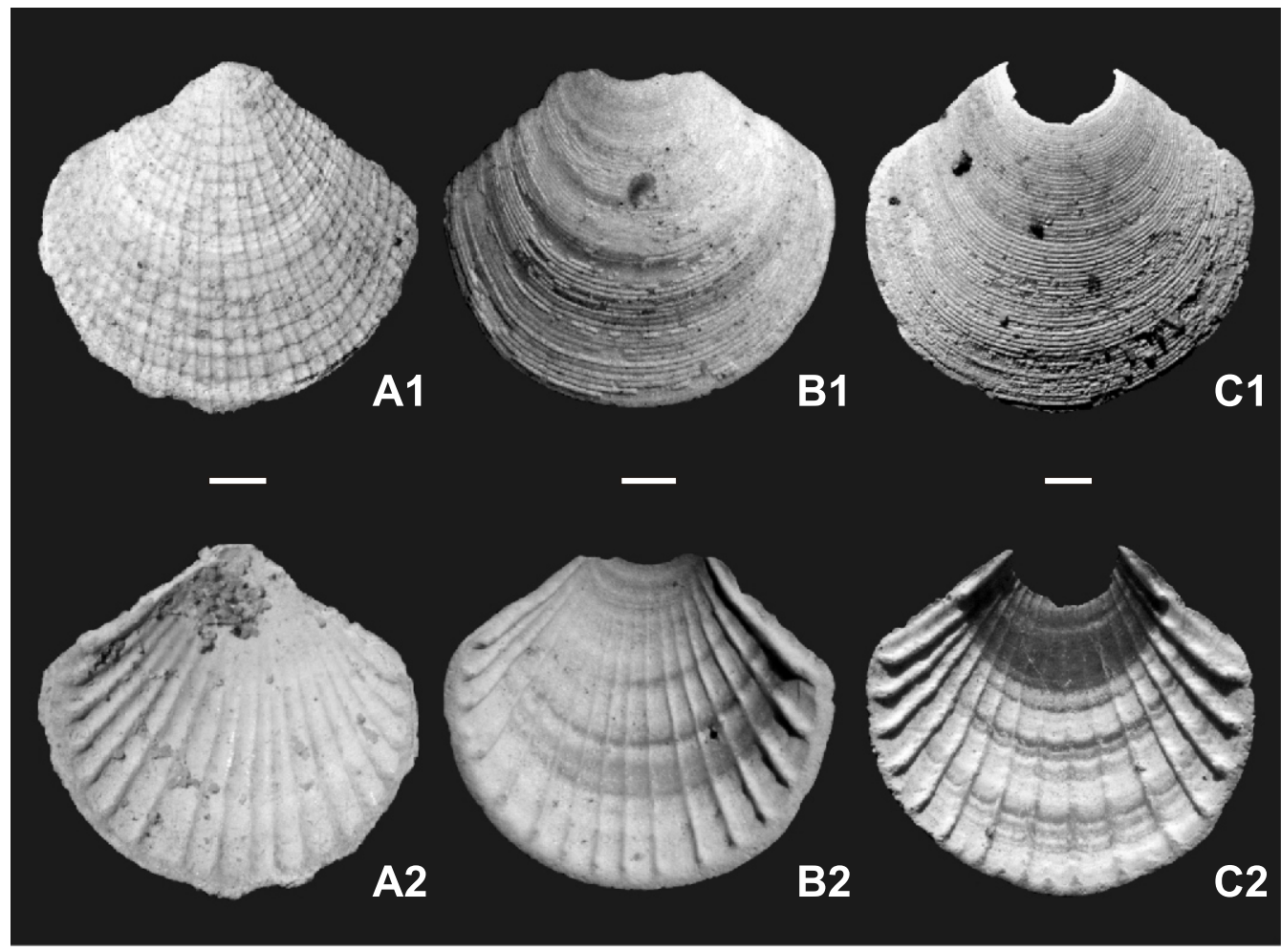

Fig. 5. Parvamussium fenestratum (Forbes, 1844) from the Roztocze Hills,

Poland, Middle Miocene (Upper Badenian)

A1, A2 - exterior and interior views of left valve, Monastyrz (MZ VIII M1-681); B1, B2 - exterior and interior views of right valve, Długi Goraj (RV, MZ VIII M1-682/1); C1, C2 - exterior and interior views of right valve, Długi Goraj (RV, MZ VIII Ml-682/2); scale bars $1 \mathrm{~mm}$ 
Variation of ornamentation. - The species discussed is characterized by different external sculptures on two valves. As noted by Poppe and Goto (1993, p. 70), Forbes (1844) used different names for the left and the right valve, viz. Pecten fenestratum and Pecten concentricus, respectively. The etymology of its younger synonyme, Pecten inaequisculptum Tiberi, 1855, does adequate justice to these morphological characters as well. In contrast to the generally constant external sculpture of the right valve, the ornamentation of the left one is quite variable. As demonstrated by Dijkstra and Goud (2002), and Dijkstra and Gofas (2004) morphological variation of the left valve is expressed by the prominence of radial lirae, and by the irregular development of second and third order lirae which are sometimes absent. Most specimens collected in the temperate to tropical eastern Atlantic (between 50 to $14^{\circ} \mathrm{N}$ ) are characterized by strongly clathrate sculpture: a radial sculpture of 8-10 irregularly spaced, larger radial lirae with intercalated smaller lirae of second and third order, crossing commarginal lamellae (Dijkstra and Gofas, 2004, fig. 4D). Similar ornamentation of the left valve has been observed on both Recent Mediterranean (Smriglio and Mariottini, 1990, pl. 1, fig. 4a) and Middle Miocene (Late Badenian) Paratethyan specimens (Csepreghy-Meznerics, 1966, pl. 2, fig. 1).

Some Atlantic specimens are, however, partially smooth: the reticulate sculpture is absent on the central part of the disc, or even on the major part of the left valve except anterior and posterior margins (Dijkstra and Gofas, 2004, fig. 4E). Sometimes, reticulate sculpture is formed by unequal radial lirae (any of second- and third-order lirae can be observed) crossed by prominent commarginal lamellae. This kind of ornamentation, present on specimens from the Cape Verde Islands (Dijkstra and Goud, 2002, figs. 5-7), conforms very well to what is observed on Mediterranean Pliocene (Lozano-Francisco, 1997, pl. 33, figs. 2, 5, 9) and on Middle Miocene (Late Badenian) Paratethyan specimens (Jakubowski and Musiał, 1977, pl. 5, fig. 11)

$\mathrm{R}$ e $\mathrm{m}$ a $\mathrm{r} \mathrm{k} \mathrm{s.-The} \mathrm{shape,} \mathrm{the} \mathrm{number} \mathrm{of} \mathrm{inner} \mathrm{riblets,} \mathrm{and}$ the ornamentation of the right valve of the Ukrainian specimens investigated are indistinguishable from the Middle Miocene Hungarian specimens found at Makkoshotyka in the Tokaj Mountains, which Csepreghy-Meznerics (1960, p. 18-19) assigned to Amussium felsineum Foresti, in spite of distinct differences in number of internal riblets. The specimens figured by Csepreghy-Meznerics (1960, pl. 35, fig. 15; 1966, pl. 2, fig. 2) have 16 and 18 riblets, respectively, while the shell of $P$. felsineum bears 10 riblets extending to four-fifths of the valve height. Hence, some of the Hungarian specimens previously attributed to $A$. felsineum undoubtedly belong to $P$. fenestratum. Consequently, the Hungarian specimens represent also new records of $P$. fenestratum for the Middle Miocene of Paratethys (Fig. 3F and G).

The Ukrainian material conforms well to the Early Pliocene (Zanclean) specimens collected by Lozano-Francisco at Parque Antena and Valerín, Spain (1997, pl. 33, figs. 1-5, 8, 9), left valves of which are sculptured with rather regularly spaced radial ribs making clathrate ornamentation with prominent overrunning commarginal lamellae (Fig. 4). The Ukrainian material is also indistinguishable from specimens assembled by
Jakubowski and Musiał (1977) from the Upper Badenian limestones in Monastyrz and Długi Goraj (Roztocze Hills). Previously assigned to Propeamussium (Parvamussium) felsineum (Foresti, 1893), these have now been properly identified as $P$. fenestratum and represent a new record for the Middle Miocene of Paratethys. These specimens are very fragile, partially fragmented, their auricles are missing. The left valve with almost regularly reticulated sculpture is slightly more convex than the right valve. Delicate commarginal lamellae ornamenting the left valve are more widely spaced than those on the right disc (Fig. 5).

A $\mathrm{f} \mathrm{fin}$ i t i e s. - The species $P$. fenestratum is somewhat similar to the type species, P. duodecimlamellatum (Bronn, 1831), known from the Early Miocene to the Pleistocene of the Mediterranean (Deperet and Roman, 1928, p. 180-182, pl. 27, figs. 2-4, 6; Erünal-Erentöz, 1958, p. 162, pl. 28, figs. 3-5; Robba, 1968, p. 488-489, pl. 37, figs. 4a-5b; Löffler, 1999, pl. 28, figs. 1-4). The similarities refer to the lamellar sculpture on the right valve but other characters differ strongly. Individuals of $P$. fenestratum have a shell almost circular in shape, approximately $8 \mathrm{~mm}$ in hight with a longer anterior auricle of the right valve sculptured with more coarse radial ribs, and a prominent clathrate sculpture on the left valve, while the shell of $P$. duodecimlamellatum is more elongated (higher than wide, especially in larger specimens), aproximatelly $30 \mathrm{~mm}$ in height, with an entirely smooth and glossy left valve. Moreover, the two species differ in the number of internal riblets. The internal surface of $P$. duodecimlamellatum bears 10-12 riblets extending to the ventral margin whereas internal surface of $P$. fenestratum is decorated with $14-20$ or even 24 riblets (observed on Spanish specimens), commencing in later growth stages (specimens less than $3 \mathrm{~mm}$ in height lack internal riblets) and terminating at some distance from the ventral margin (comp. Dijkstra and Gofas, 2004, p. 39-42).

\section{PARVAMUSSIUM SPECIES FROM THE PARATETHYS AND NEOGENE OF THE MEDITERRANEAN PROVINCE}

Examination of the taxon Parvamussium Sacco, 1897 led the senior author to the opinion that revision of its Paratethyan representatives is urgently needed, but this is beyond the scope of this paper. On the one hand, historical monographs suffer from insufficient descriptions of species. In addition, Bronn's species duodecimlamellatum and Foresti's species felsineum are based on descriptions only. On the other hand, due to the insufficient description and very poor illustrations the identification of many Paratethyan specimens is unclear and they remain to be investigated.

Research on the Oligocene-Miocene succession in the Paratethys has shown the representatives of Parvamussium to be moderately abundant in clayey facies in various basins and the genus has been recognized as biostratigraphically important. Based on extent literature (Hörnes, 1867; Kautsky, 1928; Meznerics, 1936; Zhizhchenko, 1953; Krach, 1957; Csepreghy-Meznerics, 1960, 1966; Kojumdgieva, 1960, 1969; Jakubowski and Musiał, 1977; Báldi, 1986; Bohn-Havas et al., 1987; Löffler, 1999; Schultz, 2001; Popov et al., 2009; 
Harzhauser et al., 2011), an overview of recent knowledge on representatives of Parvamussium is given below.

At least five species occurred in both Western and Central Paratethys since the Early Oligocene (early Kiscellian) up to the Middle Miocene (Late Badenian) viz., Parvamussium bronni (Mayer, 1861), P. duodecimlamellatum (Bronn, 1831), P. felsineum (Foresti, 1893), P. fenestratum (Forbes, 1844), and $P$. miopliocenicum (Ruggieri, 1949). So far no representatives of Parvamussium have been detected in the Eastern Paratethys (Nevesskaja et al., 1993; Popov et al., 1993). None of the Paratethyan Parvamussium species survived the water chemistry crisis that occurred in this area around the Badenian/Sarmatian boundary.

In the Mediterranean Neogene Province Parvamussium species are recorded from the Early Miocene (latest Burdigalian) onwards, with the exception of bronni. Only one, $P$. fenestratum, is still alive in the Mediterranean Sea.

\section{PARVAMUSSIUM BRONNI (MAYER, 1861)}

In the Paratethys Oligocene the genus Parvamussium is represented by the species $P$. bronni reported from Austria, the Czech Republic, Hungary and Ukraine. The species $P$. bronni is distinguished from all other species of Paratethyan Parvamussium by the absence of any radial sculpture and by the presence of coarse commarginal lamellae on both left and right valves (see Löffler, 1999, p. 121-123, pl. 27, figs. 1-5). The main difference between $P$. bronni and $P$. duodecimlamellatum, as pointed out by Mayer (1861 fide Löffler, 1999), is the presence of commarginal lamellae on the left valve and more distinct, always straight internal riblets in the latter species. The earliest record of $P$. bronni is that from the Zementmergel Formation at Bad Häring in Tyrol, Austria. Based on its calcareous nannofloral content, indicative of the NP22 Zone, the Zementmergel Formation is assigned to the lower Kiscellian (Lower Oligocene; Löffler, 1999). The geographically closest occurrence of $P$. bronni was noted by Oppenheim (1922, p. 20, pl. 3, figs. 14, 20) from Pouzdřany in the Lower Oligocene of Moravia, Czech Republic.

The occurrence of $P$. bronni is well-documented in various localities of the Kiscell Clay Formation in Hungary. By means of an integrated study of planktic foraminifera and calcareous nannofossils (lower part of the NP24 Zone), a late Kiscellian (Late Oligocene) age is indicated for the Kiscell Clay Formation (Báldi, 1986). This essentially Paratethyan species was also found in the Skyba Unit of the Ukrainian Carpathians. A few poorly preserved specimens of P. bronni were derived from the Middle Menilite Subformation exposed along the Chechva River (Popov et al., 2009). Dark micaceous argillite shales cropping out at Spas yielded a calcareous nannoplankton assemblage that indicates the Oligocene/Miocene boundary (the boundary between the NP25/NN1 zones).

\section{PARVAMUSSIUM DUODECIMLAMELLATUM (BRONN, 1831)}

Amongst Parvamussium species recognized within the Miocene Paratethyan fauna, $P$. duodecimlamellatum is relatively common. According to Sacco (1897), it is certainly a direct descendent of the Oligocene $P$. bronni. In the Paratethys its oldest specimens come from the Puntok Schlier Formation in Hungary and were regarded as biostratigraphically important. Based on the calcareous nannofloral content, indicative of the NN2 Zone, the Puntok Schlier Formation is assigned to the Eggenburgian (Lower Miocene; Hámor et al., 1987). Following Bohn-Havas et al. (1987) P. duodecimlamellatum and Lentipecten denudatus (Reuss) are characteristic scallop species in basin facies of the Eggenburgian within two pectinid zones i.e. the Chlamys gigas assemblage Zone and Chlamys palmata-Chlamys crestensis assemblage Zone.

It seems that Hungarian records are the oldest evidence of this Miocene to Pleistocene species. Up to now $P$. duodecimlamellatum was unknown from strata older than the lower Eggenburgian (base of the Lower Miocene). In the Mediterranean area it was reported from the uppermost Burdigalian (uppermost Lower Miocene) of Italy (Sacco, 1897). Its presence in the Chattian (Upper Oligocene) in the eastern Atlantic (Lusitanian Province) was only presumed: in the opinion of Deperet and Roman (1928, p. 180, 181), specimens from the French Atlantic coast illustrated and described by Cossmann and Peyrot (1914, pl. 13, figs. 3-7, pl. 15, fig. 24) as Variamussium cf. felsineum Foresti doubtlessly represent duodecimlamellatum. This was also stated by Erünal-Erentöz (1958) and Robba (1968). An entirely different opinion was expressed by Kautsky (1928), Meznerics (1936), Krach (1957) and Csepreghy-Meznerics (1960) who accepted the designation by Cossmann and Peyrot (1914). Thus, only re-study of the French material may allow its reliable identification.

The species $P$. duodecimlamellatum is regarded to be characteristic in the basin facies of the Lower Badenian (Baden Clay Formation) in Hungary (Bohn-Havas et al., 1987). Its occurrence together with Costellamussium cristatus badense (Fontannes) indicates the lower part of the Flabellipecten besseri assemblage Zone. The available evidence suggests that in other parts of the Central Paratethys $P$. duodecimlamellatum is rarely encountered. No specimen was detected by Kowalewski (1966) within bivalve material from more then 100 boreholes drilled through the Middle Miocene sequence in the Carpathian Foredeep Basin in Poland. Individual specimens of $P$. duodecimlamellatum are present in Lower Badenian clays in northwestern Bulgaria (Kojumdgieva 1960, p. 73, 74, pl. 25, figs. 9, 10).

Although Deperet and Roman (1928, p. 180-182) believed that Bronn's species is adequately defined, it has been frequently misidentified with $P$. felsineum from which it differs in its external ornamentaion of the left valve (see discussion in Deperet and Roman, 1928; Kautsky, 1928; Meznerics, 1936; Harzhauser et al., 2011). Kautsky's (1928, p. 254) claim that the majority of specimens from Baden and Steinebrunn in Austria as well as those from Lapugy in Romania ascribed by Hörnes $(1867$, p. 420, 421) to duodecimlamellatum represent typical felsineum was accepted by Deperet and Roman (1928, p. 183 , pl. 27 , figs. $12,12 \mathrm{a}, 13,13 \mathrm{a})$ and more recently by Schultz (2001, p. 162-164, pl. 15, figs. 10a, b, 11a, b) who considered specimens from the uppermost Lower Badenian at Baden identical to Foresti's species felsineum. Finally, due to the insufficient description and very poor illustrations the identification of many Paratethyan specimens assigned to both duodecimlamellatum (e.g., Nicorici, 1977, p. 130, 131) and to 
felsineum (e.g., Stancu et al., 1971, pl. 4, figs. 3, 4) is unclear and they still remain to be investigated.

It is established that $P$. duodecimlamellatum inhabited the Mediterranean Province at least since the late Burdigalian (Early Miocene) and persisted up to the Early Pleistocene. So far its oldest record throughout the Mediterranean is from the upper Burdigalian at Sciolze in the Turin Hills (Sacco, 1897, p. $48,49)$ whilst its youngest record is in the Lower Pleistocene strata near Grammichele in Sicily (Malatesta, 1960, p. 238). Its presence is well-documented in the central and eastern Mediterranean: in numerous, especially Pliocene outcrops in Italy (Sacco, 1897; Deperet and Roman, 1928; Ruggieri, 1950, 1957; Malatesta, 1960; Glibert and Van de Poel, 1965; Robba, 1968; Caprotti, 1974; Ceregato et al., 2007), southern Turkey (Erünal-Erentöz, 1958), and in Syria (Roger, 1939). In contrast, there are scarce data about its presence in the western Mediterranean, and its Pliocene occurrences in Spain and France (Lozano-Francisco, 1997) need confirmation, the more so as, as in the senior author's opinion, numerous Pliocene specimens from both the Var Basin in southern France and the Estapona Basin in Spain which are referred to as $P$. duodecimlamellatum by Lozano-Francisco (1997, p. 313-315, pl. 32, figs. 1-10) are actually closer to $P$. felsineum.

\section{PARVAMUSSIUM FELSINEUM (FORESTI, 1893)}

Parvamussium shells from the Central Paratethys bearing radial sculpture on the left valve were formerly always identified as $P$. felsineum. According to the number of internal riblets they certainly belong to at least two species, viz., $P$. fenestratum (14-24) and P. miopliocenicum (10-12) or P. felsineum (10-12). The latter species was introduced by Foresti (1893, p. 381, 382) on the basis of the Pliocene material found at Ponticello in the Val Savena near Bologna. According to the original description, the fragile shell (up to $c a$. $10 \mathrm{~mm}$ high) is oval in outline (wider than high), with reticulate sculpture: very numerous and easily visible thread-like radial riblets cutting less prominent and more loose commarginal lamellae form elegant reticulae, mainly near the beak. The internal surface bears ten to twelve radial riblets, sometimes with a few rudimentary interstitial ones, terminating at some distance from the ventral margin. From the end of the internal riblets to the ventral margin, the shell is very thin, transparent and finely striated. Unfortunately, no type material of felsineum was figured by Foresti. Only information that both ornamentation and arrangement of internal riblets in felsineum is similar to that in Amussium cancellatum Smith, 1885 may justify the presumption that reticulate sculpture is present on the left valve whilst the right valve is ornamented with closely spaced commarginal lamellae.

The species $P$. felsineum seems to be scarcely sparsely within the Mediterranean area. It is reported from the Pliocene of Italy (Foresti, 1893; Ruggieri, 1950). Its supposed occurrence in the eastern Middle Miocene Mediterranean is based on Roger's (1939) record from Syria. Unfortunately, no illustrations of the Mediterranean felsineum were provided.

The occurrence of $P$. felsineum in the Oligocene of the Paratethys was only presumed (Báldi, 1986). A well-documented record apparently begins with the Karpatian (Early Miocene) of Slovenia and Slovakia (Meznerics, 1936; Harzhauser et al., 2011, respectively). The Paratethyan speci- mens of $P$. felsineum appear to conform in many important respects to the typical form described from the Pliocene of Italy; although Paratethyan specimens are somewhat elongated and slightly posteriorly oblique (the type specimens are almost circular in shape, somewhat wider than high). Their left valves bear a reticulate sculpture produced by intersecting numerous (about 30 at central disc portion) prominent radial ribs and delicate commarginal growth lines in early to medium growth stages, and with prominent commarginal sculpture in late growth stages (while the type specimens show much weaker but more regular reticulate sculpture). Interstitial riblets inside left valves are not observed. Therefore, Meznerics (1936, p. 124, 125) proposed the name Amussium (Variamussium) felsineum Foresti var. styriaca for specimens with prominent reticulate sculpture on the left valve.

In the Paratethys this morphotype of $P$. felsineum with strongly radial sculpture is reported from the Lower Miocene clayey deposits (Karpatian) of Slovenia and Slovakia, and from the Middle Miocene (Lower Badenian) of Poland (Meznerics, 1936, pl. 1, figs. 1-6; Harzhauser et al., 2011, fig. 11.1-4; Krach 1957, pl. 1, figs. 1, 18, respectively).

Moreover, the presence of $P$. felsineum is documented in several outcrops of the Lower Badenian in the north-western Bulgaria (Kojumdgieva, 1969, 86, pl. 2, figs. 3-11) and in the Lower-Middle Miocene of the Vienna Basin in Austria (Deperet and Roman, 1928, pl. 27, figs. 12, 12a, 13, 13a; Schultz, 2001, 162-164, pl. 15, figs. 10, 10a, 11, 11a).

The considered morphotype styriaca resembles very closely P. fallax (Korobkov, 1936) widespread in Upper Eocene strata in Caucasus, Russia and Georgia (Korobkov, 1936, p. 70, 71, pl. 1, figs. 1-13, pl. 2, figs. 1-3; Korobkov, 1954, pl. 73, figs. 3-5), westwards to Hungary (Báldi, 1986, pl. 1, fig. 1). The two species are somewhat elongated and slightly posteriorly oblique in shape with similar reticulate sculpture visible on the left valve. Moreover, they have the same shape and number of internal riblets restricted to the proximal four-fifths of the height and lack of interstitial riblets. In the opinion of the senior author, these morphological shell features suggest that $P$. felsineum might be a direct descendent of the Eocene $P$. fallax.

\section{PARVAMUSSIUM FENESTRATUM (FORBES, 1844)}

This species, extremely rare in the Neogene Mediterranean Province has been reported from the Lower Miocene (Burdigalian) in Italy (Sacco, 1897) and from the Lower Pliocene (Zanclean) in Spain (Vera-Peláez et al., 1995; Lozano-Francisco, 1997, 1998). Recently it is also recorded as sparsely distributed through the Mediterranean Sea (Smriglio and Mariottini, 1990; Poppe and Goto, 1993; Dijkstra and Gofas, 2004; Mastrototaro et. al., 2010). Its Paratethyan record is apparently restricted to the Middle Miocene (Upper Badenian) and the first record is presented in this paper.

\section{PARVAMUSSIUM KOSLOVI (ZHIZHCHENKO, 1953)}

Zhizhchenko (1953, p. 238, 239) erected the species koslovi on the basis of Middle Miocene material derived from the Lower Badenian deposits in the Bilche-Volytsia Zone of the Carpathian Foredeep Basin in Ukraine. According to the original description, Amussium (Variamussium) koslovi shares 
many features in common with $P$. bronni. The two species have the left valve ornamented with numerous commarginal lamellae and both have the same number of internal ribs. For an unknown reason Zhizhchenko designed as a holotype a right valve of which the external character was not known to him (Zhizhchenko, 1953, pl. 2, fig. 1). The original figure of koslovi (Zhizhchenko, 1953, pl. 2, figs. 1, 2) suggests that it may be more appropriately attributed to $P$. duodecimlamellatum, with which it shares the same shape and number of internal ribs (Deperet and Roman, 1928, pl. 27, fig. 6a, b; Kojumdgieva, 1960, pl. 25, fig. 9b; Hertlein, 1969, N350, fig. C73. 2a, b).

Unfortunately, the type specimens of koslovi have not been found and the character of the external right valve is not known, and thus the validity of this species must remain uncertain. No material apart from that described by Zhizhchenko is known. Thus, a re-study of the type (apparently lost) or more material is needed for a better founded interpretation of this taxon. At present Parvamussium koslovi is considered as a nomen nudum. It may possibly represent a distinct species, but could also be regarded as conspecific with $P$. bronni or $P$. duodecimlamellatum.

\section{PARVAMUSSIUM MIOPLIOCENICUM (RUGGIERI, 1949)}

Parvamussium miopliocenicum is a new name introduced by Ruggieri for the Middle Pliocene (Piazenzian) specimens attributed by Sacco (1897) and by Deperet and Roman (1928) to $P$. felsineum. Undoubtedly, lack of illustrations of the felsineum type specimens caused Sacco (1897, p. 49, pl. 14, figs. 7-22) to assume incorrectly that Parvamussium specimens from Bordighera were identical to Foresti's species felsineum. According to Ruggieri (1950, p. 79), the original description of felsineum by Foresti (1893, p. 381, 382) leaves no doubt that Sacco's figures of felsineum from Bordighera as well as material illustrated by Deperet and Roman (1928, p. 182, 183, pl. 27, figs. 7-11) from Sant'Agata and Bordighera under the name Amussium felsineum have nothing in common with Foresti's species felsineum. They clearly represent different species as recognized by the presence of reticulate sculpture on the left valve and prominent but irregularly spaced radial lirea on the right valve. For this species Ruggieri proposed the name Amussium (Propeamussium) miopliocenicum, and designated as a holotype the specimen figured by Deperet and Roman (1928, pl. 27, figs. 9, 9a). Ruggieri stated Bordighera in Piedmont as the type locality of this species. This statement was confirmed by Robba (1968, p. 489, 490), but unfortunately it has been ignored by other authors.

The separation of miopliocenicum from felsineum is based on the external sculpture of the right valve which in the latter species bears only very closely spaced concentric lamellae whereas in the former species distinctly finer and weaker, more spaced concentric lamellae overrun irregularly spaced, delicate (8 to 12) very narrow radial lirae, projecting scales at the intersection with lamellae (Deperet and Roman, 1928, pl. 27, figs. 9a, 10a; Robba, 1968, pl 37, figs. 6a, 7a). In several right valves from Bordighera a set of commarginal lamellae closer to the ventral margin have a ragged appearance due to projections at their intersections with numerous, fine radial lines (Deperet and
Roman, 1929, pl. 27, fig. 7a). These specimens were reproduced by Hertlein as left valves [sic!] of P. felsineum (1969, N350, fig. C73. 2c).

So far, this Parvamussium species, highly variable in sculpture, has been recorded from Upper Miocene (Tortonian) deposits in Piedmont (Deperet and Roman, 1928; Robba, 1968), and from the Middle Pliocene of both Northern Italy (Sacco, 1897; Deperet and Roman, 1928; Ceregato et al., 2007) and Calabria (Ruggieri, 1950).

In contrast, there are no data about its presence in the Paratethys. But in respect to the taxonomic concept of Ruggieri (1950) it is questionable whether all specimens deposited in various museums, originally referred to felsineum, represent this species. It seems likely that some of the Bulgarian specimens sculptured with faint but distinct radial, 8 to 10 very narrow irregularly spaced ribs on the right valve (Kojumdgieva, 1969, p. 86) are actually closer to P. miopliocenicum.

\section{ECOLOGICAL REQUIREMENTS OF THE GENUS PARVAMUSSIUM}

Modern Parvamussium is a diverse, cosmopolitan genus including more than fifty species (del Rio et al., 2008 with references; Dijkstra and Maestrati, 2008, 2010). The abundance and diversity of Parvamussium reflects its preference for a temperate and warm Pacific: researches by Dijkstra and Maestrati (2008, 2010) have revealed 22 species of Parvamussium from the South Pacific that are restricted to, or are most common in, the bathyal zone.

Few data concerning environmental requirements are available for the fossil representatives of Parvamussium. Nevertheless, palaeontological findings suggest a similar geographical preference to that in the present day. According to the records the earliest occurrence of Parvamussium apparently begins in the Early Cretaceous within circum-Pacific area (Sundberg, 1989 with references). At least six species are reported from the Lower Cretaceous of Kyushu, Japan, Sarawak and Borneo (Tamura, 1973 fide Sundberg, 1989). Three other species are relatively common in the Upper Cretaceous deeper water mudstones in southern California, North America (Sundberg, 1989).

So far no species of Parvamussium is recorded from the Upper Cretaceous of Southern Hemisphere but since the Paleogene, Parvamussium has been noted from New Zealand, southern Australia and southern South America (del Rio et al., 2008). These findings should be complemented with at least six species recorded from the Eocene deposits of the northern Caucasus (Korobkov, 1936). Contrary to Cretaceous records from the Northern Hemisphere, the oldest palaeontological data of Parvamussium from the Southern Hemisphere seem to suggest that at least during the Early Paleogene, Parvamussium inhabited shallow environments (del Rio et al., 2008). Its occurrence was detected in the shallow marine (littoral) carbonate sequence within Paleocene (Danian) formations in Patagonia, Argentina. In the opinion of del Rio et al. (2008), Parvamussium has drastically changed its ecological requirements during the Late Oligocene to Middle Miocene. According to Beu and Maxwell (1990), its occurrence in the Miocene 
of New Zealand was recognized within bathyal molluscan associations that seemed to have lived in the upper part of the zone (ca. 200-800 m).

At present, only the family Propeamussiidae Abbott of the subclass Pteriomorphia, increases its diversity with increasing water depth (Beu and Maxwell, 1990). Very fragile, thin-shelled, usually small (2 to $15 \mathrm{~mm}$ high) modern representatives of Parvamussium are mostly adapted to life in the bathyal zone and they are infrequent in depths of less than $60 \mathrm{~m}$. Previous studies suggest that only two species, viz. P. scitulum (Smith, 1885) and P. pauciliratum (Smith, 1903) inhabit littoral and sublittoral zones (Dijkstra, 1991). The latter species was sampled from sublittoral depths $(27-45 \mathrm{~m})$ in the Indonesian Archipelago (Dijkstra, 1995) but subsequent research documents its occurrence deeper than previously known. It inhabits the bathyal zone (509-522 m) near the Solomon Islands (Dijkstra and Maestrati, 2008).

Little bathymetric information is provided for the Paratethyan Parvamussium species. The bivalve fauna recorded by Báldi (1986) from the Oligocene Kiscell Clay Formation in Hungary includes the "mud pecten" Parvamussium bronni (Mayer) [originally identified as a subspecies of Propeamussiumi (Parvamussium) duodecimlamellatum], one of the most common molluscs. The depositional environment is referred to the upper part of the bathyal zone (depth 200-1000 m), which is supported by the presence of the associated benthic foraminifera, the barnacle genus Scalpellum Leach, the lobster genus Thaumastocheles Bate and the nautiloid genus Aturia Bronn (Baldi, 1986). A similar bathymetric requirement for P. bronni was estimated by Löffler (1999).

Apart from P. bronni, the species P. felsineum (Foresti) is known to occur in the upper part of the bathyal zone. Recently, it was recognized within the Karpatian molluscan assemblages from the Slovak Republic (Harzhauser et al., 2011). Along with P. duodecimlamellatum (Bronn), it has also been reported from Lower Badenian shallow clayey facies in northwestern Bulgaria (Kojumdgieva, 1960, 1969).

The only species of the Paratethyan Parvamussium that is extant is $P$. fenestratum (Forbes), characterized by a wide bathymetric range, extending from 99 to $2600 \mathrm{~m}$. It is one of four Parvamussium species inhabiting the northeastern Atlantic viz. P. fenestratum (Forbes, 1844), $P$. intuslaevis Dijkstra et Gofas, 2004, P. permirum (Dautzenberg, 1925), and P. propinquum (Smith, 1885) (Dijkstra and Gofas, 2004; Olabarria, 2005). Out of these species only P. fenestratum (Forbes, 1844) inhabits the Mediterranean Sea (Poppe and Goto, 1993), living on muddy bottoms between scleractinian coral banks at 300-530 m depth (Mastrototaro et al., 2010). Thus, its scarceness in the Paratethys can be explained by the absence of favourable environments. The species was described from Upper Badenian sublittoral facies in the Roztocze Hills, Poland represented by coralline-algal marly limestones (Jakubowski and Musiał, 1977). Based on physical and palaeontological evidences Maslov and Utrobin (1958) postulated that the Ternopil Beds (containing the P. fenestratum shells) were deposited at a depth of a few tens of metres, below fair-weather wave base.

Acknowledgements. The senior author express warm thanks to Dr. M. del Carmen Lozano-Francisco (Museum of Palaeontology in Estapona) for supplying Pliocene specimens of Parvamussium fenestratum, to Dr. A. Dulai (Hungarian Natural History Museum in Budapest) for the kind assistance at the Csepreghy-Meznerics collection and documentation of specimens, and to D. Nast, M.Sc. (Polish Academy of Sciences Museum of the Earth in Warsaw) who took the photographs. Sincere thanks are addressed to Dr. S̆. Hladilova (Institute of Geological Sciences, Masaryk University Brno) and Dr. M. A. Bitner (Institut of Paleobiology, Polish Academy of Sciences, Warsaw) for their constructive reviews of the manuscript.

\section{REFERENCES}

ANDREYEVA-GRIGOROVICH A.S., KULCHYTSKY Y.O., GRUZMAN A.D., LOZYNYAK P.Y., PETRASHKEVICH M.I., PORTNYAGINA L.O., IVANINA A.V., SMIRNOV S.E., TROFIMOVICH N.A., SAVITSKAYA N.A. and SHVAREVA N.J. (1997) - Regional stratigraphic scheme on Neogene formations of the Central Paratethys in the Ukraine. Geol. Carpath., 48: 123-136.

ANDRZEJOWSKI A. (1830) - Notice sur quelques coquilles fossiles de Volhynie et Podolie. Bull. Soc. impér. Natur. Moscou, 2: 90-104.

ANDRZEJOWSKI A. (1833) - Coquilles fossiles de Volhynie et de Podolie (suite). Bull. Soc. impér. Natur. Moscou, 6: 437-451.

BÁLDI T. (1986) - Mid-Tertiary stratigraphy and paleogeographic evolution of Hungary. Akadémiai Kiadó Publications. Budapest.

BEU A.G. and MAXWELL P.A. (1990) - Cenozoic Mollusca of New Zealand. New Zealand Geol. Surv. Paleont. Bull., 58: 1-58.

BIELER R., CARTER J.G. and COAN E.V. (2010) - Classification of Bivalve families. Malacologia, 52 (2): 1-184.

BOHN-HAVAS M., BÁLDI T., KÓKAY J. and HALMAI J. (1987) Pectinid assemblage zones of the Miocene in Hungary. Ann. Inst. Geol. Publ. Hung., 70: 441-446.

BRONN H.G. (1831) - Italiens Tertiär-Gebilde und deren organische Einschlüsse. Karl Groos. Heidelberg.
CAPROTTI E. (1974) - Molluschi del Tabianiano (Pliocene inferiore) della Val d'Arda. Loro connessioni temporali e spaziali. Conchiglie, $10(1-2): 1-47$

CEREGATO A., RAFFI S. and SCARPONI D. (2007) - The circalittoral/bathyal paleocommunities in the Middle Pliocene of Northern Italy: the case of the Korobkoviella oblonga-Jupiteria concava paleocommunity type. Geobios, 40: $555-572$.

COSSMANN M. and PEYROT A. (1914) - Conchologie néogénique de l'Aquitaine. Vol. II Pélécypodes (fasc. 2). A. Saugnac and E. Drouillard, Bordeaux.

CSEPREGHY-MEZNERICS I. (1960) - Pectinidés du Néogene de la Hongrie et leur importance stratigraphique. Mém. Soc. Géol. France, Nouv. Sér., 39: 1-58.

CSEPREGHY-MEZNERICS I. (1966) - Les mollusques des sédiments miocènes marins de la Montagne de Tokaj (N-E Hongrie). Ann. Hist.-Natur. Mus. Natur. Hung. Pars Miner. Paleont., 58: 103-129.

Del RIO C.J., BEU A.G. and MARTINEZ S.A. (2008) - The pectinoidean genera Delectopecten Stewart, 1930 and Parvamussium Sacco, 1897 in the Danian of Northern Patagonia, Argentina. N. Jb. Geol. Paläont. Abh., 249: 281-295. 
DEPÉRET Ch. and ROMAN F. (1928) - Monographie des pectinidés néogènes de l'Europe et des regions voisines. Mém. Soc. Géol. France, Nouv. Sér., 4 (4): 169-194.

DIDKOWSKI V.Ya., PRISJAZHNIUK V.A., LJUL'EVA S.A. and LJUL'EV Yu. B. (1981) - Sarmatskiye otlozheniya Mogilevskogo Pridnestrovya. Geol. Zh., 41 (4): 107-113.

DIJKSTRA H.H. (1991) - A contribution to the knowledge of the pectinacean Mollusca (Bivalvia: Propeamussiidae, Entoliidae, Pectinidae) from the Indonesian Archipelago. Zoologische Verhandelingen, 271: 1-57.

DIJKSTRA H.H. (1995) - Bathyal Pectinoidea (Bivalvia: Propeamussiidae, Entoliidae, Pectinidae) from New Caledonia and adjacent areas. Mém. Mus. Natur. Hist. Natur., 167: 9-73.

DIJKSTRA H.H. and GOUD J. (2002) - Pectinoidea (Bivalvia, Propeamussiidae and Pectinidae) collected during the Dutch CANCAP and MAURITANIA expeditions in the southeastern region of the North Atlantic Ocean. Basteria, 66: 31-82.

DIJKSTRA H.H. and GOFAS S. (2004) - Pectinoidea (Bivalvia: Propeamussiidae and Pectinidae) from some northeastern Atlantic seamounts. Sarsia, 89: 33-78.

DIJKSTRA H.H. and MAESTRATI P. (2008) - New species and new records of deep-water Pectinoidea (Bivalvia: Propeamussiidae, Entoliidae and Pectinidae) from the South Pacific. Mém. Mus. Natur. Hist. Natur., 196: 77-113.

DIJKSTRA H.H. and MAESTRATI P. (2010) - Pectinoidea (Mollusca, Bivalvia, Propeamussiidae, Entoliidae and Pectinidae) from the Austral Islands (French Polinesia). Zoosystema, 32 (2): 333-358.

DIJKSTRA H.H., WARÉN A. and GUDMUNDSSON G. (2009) Pectinoidea (Mollusca: Bivalvia) from Iceland. Marine Biol. Res., 5: 207-243.

Du BOIS de MONTPÉREUX F. (1831) - Conchiologie fossile et aperçu gčognostique des formations du Plateau Wolhyni-Podolien. Simon Schropp et Comp., Berlin.

EICHWALD E. (1829) - Zoologia specialis, quam expositis animalibus tum vivis, tum fossilibus potissimum Rossiae in universae et Poloniae in specie edidit. Zawadzki, Vilnius.

EICHWALD E. (1830) - Naturhistorische Skizze von Lithauen, Volhynien und Podolien in geognostisch-mineralogischer, botanischer und zoologischer Hinsicht. Zawadzki, Vilnius.

EICHWALD E. (1850) - Palaeontologiya Rossii. Novyj period. E. Prac, Sankt Peterburg.

EICHWALD E. (1853) - Leathaea Rossica ou paléontologie de la Russie. Derničre période. E. Schweizerbart, Stouttgart.

ERÜNAL-ERENTÖZ L. (1958) - Mollusques de Néogene des Bassin de Karaman, Adana et Hatay (Turquie). Publ. Inst. Etud. Rech. Miner. Turquie. Sér. C, 4: 1-232.

FORBES E. (1844) - Report on the Mollusca and Radiata of the Aegean Sea, and on their distribution, considered as bearing on geology. Report of the British Association for the Advancement of Science for 1843: 130-193.

FORESTI L. (1893) - Enumerazione dei Brachiopodi e dei Molluschi pliocenici dei dintorni de Bologna. Parte II. Boll. Soc. Malacologica Ital., 18: 185-413.

FRIEDBERG W. (1932) - Die Pectiniden des Miocänns von Polen und ihre stratigraphische Bedeutung. Bull. Internat. Acad. Pol. Sc. Lett. Cl. Sc. Math. Natur., Sér. B, 5-6: 47-66, 113-122.

FRIEDBERG W. (1934-1936) - Mollusca miocaenica Poloniae. Pars II Lamellibranchiata (in Polish). Polskie Towarzystwo Geologiczne, Kraków.

FRIEDBERG W. (1938) - Lamellibranchiata. Bull. Intern. Acad. Pol. Sc. Lett. Cl. Sc. Math. Natur., Sér. B, 12: 3-42.

GARECKA M. and OLSZEWSKA B. (2011) - Correlation of the Middle Miocene deposits in SE Poland and western Ukraine based on foraminifera and calcareous nannoplankton. Ann. Soc. Geol. Pol., 81: 309-330.

GEDL P and PERYT D. (2011) - Dinoflagellate cyst, palynofacies and foraminiferal records of environmental changes related to the Late Badenian (Middle Miocene) transgression at Kudryntsi (western Ukraine). Ann. Soc. Geol. Pol., 81: 331- 349.

GLIBERT M. and van de POEL L. (1965) - Les bivalvia fossiles du Cénozoïque étranger des collections de 1'Institut Royal des Sciences naturelles de Belgique. Mém. Inst. Royal Sc. nat. Belg. Duexième Sér., 78: 2-105.

HÁMOR G., BÁLDI T., BOHN-HAVAS M., HABLY L., KÓKAY J., HALMAI J., HAJÓS M., KOKÓJ J., KORDOS L., KORECZ-LAKY I., NAGY E., NAGYMAROY A. and VÖLGYI L. (1987) - The bio-, litho- and chronostratigraphy of the Hungarian Miocene. Ann. Inst. Geol. Publ. Hung., 70: 351-353.

HARZHAUSER M., MANDIC O and SCHLÖGL J. (2011) - A late Burdigalian bathyal mollusc fauna from the Vienna Basin (Slovakia). Geol. Carpath., 62: 211-231.

HERTLEIN L.G. (1969) - Family Pectinidae Rafinesque, 1815. In: Treatise on Invertebrate Paleontology (ed. R. C. Moore), Part N, 1. Mollusca 6, Bivalvia: 348-373. The Geological Society of America and University of Kansas Press, Lawrence.

HILBER V. (1882) - Neue und venig bekannte Conchylien aus dem Ostgalizischen Miocän. Abh. K.-K. Geol. R.-A, 7 (6): 1-33.

HÖRNES, M. (1867) - Die fossilen Mollusken des Tertiär-Beckens von Wien. Band II: Bivalven. Abh. K.-K. Geol. R.-A, 4: 343-430.

JAKUBOWSKI G. and MUSIAE T. (1977) - Lithology and fauna from the Upper Tortonian sands of Monastyrz and Długi Goraj (Southern Roztocze Poland). Prace Muz. Ziemi, 26: 63-126.

KAUTSKY F. (1928) - Die biostratigraphische Bedeutung der Pectiniden des niederösterreichischen Miozäns. Ann. Naturhist. Mus. Wien, 42: 245-273.

KAZAKOVA W.P. (1952) - Stratygrafya i fauna plastinchatozhabernyh molluskov srednemiocenovyh otlozhenij Opol'ya. Trudy Mosk. Geol-razvied. Inst., 27: 171-263.

KOJUMDGIEVA E. (1960) - Le Tortonien du type viennois (in Bulgarian with French summary). In: Les fossilles de Bulgarie (eds. E. Kojumdgieva and B. Strachimirov), VII, Tortonien: 1-246. Académie des Sciences de Bulgarie, Sofia.

KOJUMDGIEVA E.I. (1969) - Quelques Pectinidés du Tortonien de la Bulgarie (in Bulgarian with French summary). Bull. Geol. Inst., Ser. Paleont., 18: 83-88.

KOROBKOV I.A. (1936) - Contribution to the knowledge about the Paleogene faunas from the Northern Caucasus (in Russian with English summary). Trudy geologicheskoy sluzhby Groznefti, 9: 32-84.

KOROBKOV I.A. (1954) - Spravochnik i metodicheskoe rukovodstvo po tretichnym molluskam. Plastinchatozhabernyye. Gostoptehizdat. Leningrad.

KOWALEWSKI K. (1966) - Miocen odcinków południowosandomierskiego, tarnobrzeskiego i chmielowsko-baranowskiego i ich stosunek do obszarów sąsiednich. Biul. Inst. Geol., (unnumbered): 7-143.

KRACH W. (1957) - Pectinidae from upper Miocene deposits of Upper Silesia (in Polish with English summary). Acta Geol. Pol., 7: 321-359.

KRACH W. and NOWAK W. (1956) - Le miocène des environs d'Andrychów (in Polish with French summary). Rocz. Pol. Tow. Geol., 25: 9-54.

KUDRIN L.N. (1966) - Stratigrafiya, fatsii i ekologichesky analiz fauny paleogenovykh i neogenovykh otlozheny Predkarpatya. Izd. Lvovsk. Univ., Lvov.

KUROVETS I., PRYTULKA G., SHPOT Y. and PERYT T.M. (2004) Middle Miocene Dashava Formation sandstones, Carpathian Foredeep, Ukraine. J. Petrol. Geol., 27: 373-388.

LOZANO-FRANCISCO M.C. (1997) - Los Bivalvos del Plioceno de la Provincia de Málaga. Unpubl. P.Dh. Thesis; Univestidad de Málaga.

LOZANO-FRANCISCO M.C. (1998) - Los Bivalvos (Mollusca, Bivalvia) del Plioceno de la Provincia de Málaga, Espańa. Malacos, 6-7: 16-58.

LÖFFLER S. (1999) - Systematische Neubearbeitung and paläoökologische Aspekte der unteroligozänen Mollukenfauna aus den Zementmergel von Bad Häring (Unterinntal, Tirol). Tübingen Geowissensch. Arb., 54: 1-207.

LYULYEVA S.A. (2009) - Calcareous nannoplankton of the Sarmatian deposits of Ukraine (in Russian with English abstract). Sbornik nauchnykh trudov Instituta geologicheskikh nauk NAN Ukrainy 2009: 322-329.

MALATESTA A. (1960) - Malacofauna Pleistocenica di Grammichele (Sicilia). Mem. Serv. Descr. Carta Geol. It., 12: 10-391. 
MASLOV V.P. and UTROBIN V.N. (1958) - Rasprostraneniye tretichnykh bagryanykh vodorostey Ukrainskoy SSR i svyaz ikh s transgressiyami morey. Izv. Akad. Nauk SSSR, Ser. Geol., 12: 73-93.

MASTROTOTARO M., D’ONGHIA G., CORRIERO G., MATARRESE A., MAIORANO P., PANETTA P., GHERARDI M., LONGO C., ROSSO A., SCIUTO F., SANFILIPPO R., GRAVILI C., BOERO F., TAVIANI M. and TURSI A. (2010) - Biodiversity of the white coral bank off Cape Santa Maria di Leuca (Mediterranean Sea): an update. Deep-Sea Res. II, 57: 412-430.

MEZNERICS I. (1936) - Die Schlierbildungen des mittelsteirischen Beckens. Mitt. Naturwiss. Ver. Steiermark, 73: 118-140.

NEVESSKAJA L.A., GONCHAROVA I.A., PARAMONOVA N.P., POPOV S.V., BABAK E.V., BAGDASARJAN K.G. and VORONINA A.A. (1993) - Opredelitel' miocenovykh dvustvorchatykh molluskov Yugo-Zapadnoy Evrazii. Trudy PIN RAN, 247: $1-412$.

NIEDŹWIEDZKI J. (1889) - Ergänzung zur Fossilliste der Miocäns bei Podhorce in Ostgalizien. Verh. K.-K. Geol. R.-A., 6: 134-135.

NICORICI E. (1977) - Les Pectinidés badénies de Roumanie. Mém. Inst. Géol. Géoph., 26: 119-160.

OLABARRIA C. (2005) - Patterns of bathymetric zonation of bivalves in the Porcupine Seabight and adjacent Abyssal plain, NE Atlantic. Deep-Sea Res. I, 52: 15-31.

OPPENHEIM P. (1922) - Über Alter und Fauna des Tertiärhorizontes der Niemtschitzer Schichten in Mähren. Selbstverlage des Verfassers. Berlin.

PERYT D. (1999) - Calcareous nannoplankton assemblages of the Badenian evaporites in the Carpathian Foredeep. Biul. Państw. Inst. Geol., 387: 158-161

POPOV S.V., VORONINA A.A. and GONCHAROVA I.A. (1993) Stratygrafiya i dvustvorchatyye molluski oligotsena-nizhnego miocena Vostochnogo Paratetysa. Trudy PIN RAN, 256: 1-207.

POPOV S.V., STUDENCKA B. and AMITROV O.A. (2009) - Oligocene molluscan fauna of the Ukrainian Carpathians (in Russian with English abstract). Sbornik nauchnykh trudov Instituta geologicheskikh nauk NAN Ukrainy 2009: 282-286.

POPPE G.T. and GOTO Y. (1993) - European Seashells. Volume II (Scaphopoda, Bivalvia, Cephalopoda). Christa Hemmen Verlag, Wiesbaden.

PUSCH G.G. (1837) - Polens Paläontologie oder Abbildung und Beschreibung der vorzüglichsten und der noch unbeschrieben Petrefakten aus den Gebirgsformationen in Polen, Volhynien und den Karpathen. E. Schweizerbart's Verlagshandlung, Stuttgart.

ROBBA E. (1968) - Molluschi del Tortoniano-tipo (Piemonte). Riv. It. Paleont. Strat., 74 (2): 457-646.
ROGER J. (1939) - Le genre Chlamys dans les formation Néogene de l'Europe. Conclusions générales sur la répartition géographique et stratigraphique des Pectinides du Tertiaire au Recent. Mém. Soc. Géol. France, Nouv. Sér., 17 (2-4): 1-294.

RUGGIERI G. (1950) - Contribuzione alla conoscenza della malacofauna e dell stratigrafia del Pliocene e del Quaternario. Ann. Mus. Geol. Bologna, Sér. 2, 21: 65-90.

RUGGIERI G. (1957) - Molluschi Pliocenici sopravvissuti nel Calabriano. Atti Soc. Tosc. Sc. Natur. Resid. Pisa, Sér. 2, 64: 80-87.

SACCO F. (1897) - I Molluschi die terreni terziarii del Piemonte e della Liguria. Parte 24. Carlo Clausen. Libraio della 1'Accademia delle Scienze, Torino.

SCHULTZ O. (2001) - Bivalvia neogenica (Nuculacea-Unionacea). In: Catalogus Fossilium Austriae (ed. W.E. Piller). Band 1, Teil 1. Verlag der Österreichischen Akademie der Wissenschaften, Wien.

SMRIGLIO C. and MARIOTTINI P. (1990) - Descrizione di una nuova specie di Pectinidae (Rafinesque, 1815) per il Mar Mediterraneo: Cyclopecten brundisiensis n. sp. e considerazioni su alcune specie appartenenti ai generi Cyclopecten (Verrill, 1897) e Propeamussium De Gregorio, 1884. Boll. Malacol., 26 (1-4): 1-18.

STANCU J., GHEORGHIAN M.D. and POPESCU A. (1971) - Studii stratigrafice asupra miocenului din versantul nordic al Dunării, ĭntre Dubova și Pojejena (Carpații meridionali). Dări de seamă ale şedințelor, 57, (4. stratigrafie): 119-133.

STUDENCKA B. and JASIONOWSKI M. (2011) - Bivalves from the Middle Miocene reefs of Poland and Ukraine: a new approach to Badenian/Sarmatian boundary in the Paratethys. Acta Geol. Pol., 61 (1): 79-114.

STUDENCKA B., GONTSHAROVA I.A. and POPOV S.V. (1998) - The bivalve fauna as a basis for reconstruction of the Middle Miocene history of the Paratethys. Acta Geol. Pol., 48 (3): 285-342.

SUNDBERG F.A. (1989) - Propeamussium species (Bivalvia: Propeamussiidae) from the Upper Cretaceous of southern California. J. Paleont., 63 (1): 53-63.

TEISSEYRE W. (1895) - O charakterze fauny kopalnej Miodoborów. Sprawozdania Komisyi Fizyograficznej, 30: 82-92.

VERA-PELÁEZ J.L., LOZANO-FRANCISCO M.C., MUNIZ-SOLIS R., Gili C., MARTINELL J., DOMENÉCH R., PALMQVIST P. and MERCHÁN A. (1995) - Estudio preliminar de la malacofauna del Pliocene de Estapona (Malaga, Espańa). Iberius, 13: 93-117.

WALLER T.R. (2006) - Phylogeny of families in the Pectinoidea (Mollusca: Bivalvia): importance of the fossil record. Zool. J. Linnean Soc., 148: 313-342.

ZHIZHCHENKO B.P. (1953) - Pectinidae miotsena Chernovitskogo rayona. Trudy VNIIGAZ: 225-242. Gostoptekhizdat, Moscow. 